\title{
Removal of Arsenic and Coliform Bacteria by Modified Sand Filter With Slag and Zeolite from Drinking Water
}

\author{
Ali Abdolahnejad, ${ }^{1}$ Negar Jafari, ${ }^{2,3}$ Afshin Ebrahimi, ${ }^{4,5,}$ Amir Mohammadi, ${ }^{1}$ and Hossein \\ Farrokhzadeh ${ }^{4,5}$ \\ ${ }^{1}$ Department of Environmental Health Engineering, School of Health, Shahid Sadoghi Yazd University of Medical Sciences, Yazd, IR Iran \\ ${ }^{2}$ Environment Research Center, Isfahan University of Medical Sciences, Isfahan, IR Iran \\ ${ }^{3}$ Student Research Committee and Department of Environmental Health Engineering, School of Health, Isfahan University of Medical Sciences, Isfahan, IR Iran \\ ${ }^{4}$ Environment Research Center, Research Institute for Primordial Prevention of Non-Communicable Disease, Isfahan University of Medical Sciences, Isfahan, IR Iran \\ ${ }^{5}$ Department of Environmental Health Engineering, School of Health, Isfahan University of Medical Sciences, Isfahan, IR Iran \\ Corresponding author: Afshin Ebrahimi, Environment Research Center, Research Institute for Primordial Prevention of Non-Communicable Disease, Isfahan University of \\ Medical Sciences, Isfahan, IR Iran. E-mail: a_ebrahimi@hlth.mui.ac.ir
}

Received 2016 July 24; Revised 2016 November 20; Accepted 2016 December 23.

\begin{abstract}
Background: Among the various adverse pollutants in water, coliform bacteria and arsenic are very important. Drinking of arseniccontaminated water has become a serious threat to public health and has affected millions of people across the world.

Objectives: The aim of this study was to investigate the removal of arsenic and coliform bacteria from drinking water in small communities with the use of a conventional Slow Sand Filter (SSF) and modified filter by slag (SMF) and Zeolite (ZMF).

Methods: In this study, initial concentrations of arsenic were $0.073,0.11,0.171,0.21,0.24$, and $0.33 \mathrm{mg} / \mathrm{l}$ and the initial number of coliform bacteria was $4 * 10^{6} \mathrm{MPN} / 100 \mathrm{~mL}$. Arsenic and coliform bacteria samples were taken every 24 and 48 hours, respectively. Concentration of arsenic was analyzed by Inductively coupled plasma atomic emission spectroscopy (ICP-AES) and the total and fecal coliforms were measured by multiple probable number (MPN) 9-tubes method.

Results: The results showed that the mean removal efficiency of arsenic (mean $0.189 \mathrm{mg} / \mathrm{L}$ ) by SSF, SMF, and ZMF was 33.7\%, 51.5\%, and $66.2 \%$, respectively. It was shown that the filter modified by zeolite had more efficiency in arsenic removal because of higher cation exchange capacity (CEC) than any other media. The removal efficiencies of coliform bacteria by SSF, SMF, and ZMF were 1.97,1.98, and $1.99 \log$, respectively.

Conclusions: This treatment method can be used as a simple, cheap, and convenient technique for arsenic and coliform bacteria removal from small communities' drinking water resources.
\end{abstract}

Keywords: Modified Filter, Slag, Zeolite, Arsenic, Drinking Water Resources

\section{Background}

About $80 \%$ of communicable diseases around the world are waterborne $(1,2)$. Access to improved drinking water is unavailable to an estimated 884 million people around the world, most of which live in rural, dispersed, and often remote communities in developing countries (3).

There are many pollutants in water, such as pathogenic organisms, fecal matter, suspended solids, algae, organic matter, and harmful chemicals. Among the various adverse pollutants, coliform bacteria and arsenic are very important $(4,5)$. Coliform bacteria are the indicator of water contaminated with human or animal wastes and if these exist in water, it is unsafe for drinking purposes. Generally, all bacteria are not harmful but other microbes could cause short-term health effects, such as diarrhea, cramps, nausea, headaches, or other symptoms $(5,6)$.

Arsenic (As) contamination in groundwater, used for drinking purposes, has been envisaged as a problem of global concern (7). Elevated arsenic concentration in drinking water sources is an issue of global concern and threatens over 200 million people worldwide, especially in Asia. Arsenic has been reported in groundwater of Bangladesh, Cambodia, China, Taiwan, Mongolia, India, Japan, Myanmar, Nepal, Pakistan, Thailand, Viet Nam, and Iran (8-10). In the rural areas of west and northwest Iran, Kurdistan and Azerbaijan provinces, arsenic contamination of groundwater was reported (9). Arsenic exists in multiple oxidation states $(+5,+3,0$ and -3$)$; arsenate As (V) and arsenite As (III) are the most common inorganic forms of arsenic in aquatic environments. Arsenate species $\left(\mathrm{AsO}_{4}{ }^{3-}, \mathrm{HAsO}_{4}{ }^{2-}\right.$, and $\mathrm{H}_{2} \mathrm{AsO}_{4}{ }^{-}$) are considered as soft acid and mostly stable in oxygen rich environments. However, arsenite species $\left(\mathrm{AsO}_{3}{ }^{3-}, \mathrm{AsO}_{2} \mathrm{OH}^{2-}\right.$, $\mathrm{As}(\mathrm{OH})_{4}{ }^{-}$and $\mathrm{As}(\mathrm{OH})_{3}$ ) are stable in moderate reducing environments, such as underground water. Furthermore, As (III) has higher toxicity

Copyright (c) 2017, Journal of Health Scope. This is an open-access article distributed under the terms of the Creative Commons Attribution-NonCommercial 4.0 International License (http://creativecommons.org/licenses/by-nc/4.0/) which permits copy and redistribute the material just in noncommercial usages, provided the original work is properly cited. 
and greater mobility, which needs to be oxidized for better adsorbption of As $(\mathrm{V})(8,11)$.

Arsenic in aqueous systems can originate from natural sources (e.g., geochemical reactions and volcanic emissions) as well as anthropogenic activities (such as metal mining, industrial waste discharge, and agricultural use of arsenical pesticides) (12). These sources could pollute water systems, especially groundwater aquifers from different sources. Drinking of arsenic-contaminated water has become a serious threat to public health, and has affected millions of people across the world (Kong et al. 2014). Ingestion of inorganic arsenic could result in both cancer (skin, lung, and urinary bladder) and non-cancer effects (13). Long-term exposure to high levels of arsenic may cause serious health problems, including skin, cardiovascular, neurological, renal, and respiratory diseases in humans $(8,14)$. To reduce the incidence of waterborne diseases and make the water suitable for human consumption, the removal of water pollutants are absolutely necessary $(4,15)$.

The world health organization (WHO) has set guidelines of $0.01 \mathrm{mg} / \mathrm{L}$ and $0 \mathrm{MPN} / 100 \mathrm{~mL}$ for arsenic and coliform bacteria in drinking water, respectively (16).

Different treatment technologies to reduce concentrations of arsenic in drinking water are available or under investigation. Some of these include coagulation $(17,18)$, sedimentation-filtration $(19,20)$, nanofiltration $(21,22)$, reverse osmosis $(21,23)$, fluidized-bed sand reactor, and subsurface groundwater treatment (24). Nevertheless, these technologies are inappropriate for application in rural communities (25). Therefore, in these communities, simplistic design, and minimum maintenance and operating cost are some important factors that require consideration (26). More than 50 household treatment technologies exist worldwide for water pollution removal (24). Arsenic removal by low-cost adsorbents, such as filter based granulated adsorbents, has been the most promising technique, which meets all the mentioned criteria offering reliable and efficient performance for communities living in scattered settlements $(8,25,27)$. However, natural adsorbents are favorable for their low-cost and abundant sources, yet, some studies have shown that they had no sufficient capacity to remove total arsenic (As (III) + As (V)) from water resources $(28,29)$. For example, natural adsorbents, such as limestone, and zeolites like clinoptilolite, chabazite, and sandy soils have been studied for arsenic removal in water (30). The acceptable level of concentration of arsenic in drinking water is $0.01 \mathrm{mg} / \mathrm{L}$ (31). Pravin et al. in 2009 used conventional and modified filters to remove coliform bacteria and arsenic. The study results showed that the efficiency of conventional and modified filters to remove coliform bacteria were $99.95 \%$ and $99.99 \%$, and in the removal of arsenic were $14 \%$ and $75 \%$, respectively (6). The study results of Aviles et al. in 2013 showed that the efficiency of the domestic filter in arsenic removal was $95.4 \%$ (initial concentration of $0.11 \mathrm{mg} / \mathrm{L}$ ) (24). The considerable removal efficiencies of arsenic were also reported by several studies that used household filter, ceramic filter, and modified natural zeolite filter in Vietnam, Bangladesh, and Turkey (13, 32, 33).

A study, done in 2011, showed that adsorbent characterization of natural zeolites could be affected by parameters, such as their surface morphologies, chemical composition, physical properties, and specific surface areas (32). In another study in 2002, the researchers used granular slag columns for lead removal. It was concluded that the apparent mechanisms of lead removal by this column were sorption (ion exchange and adsorption) on the slag surface and precipitation (34).

\section{Objectives}

The aim of this study was the use of a native and lowcost absorbent (such as clinoptilolite) and unusable material (such as blast furnace slag), as a filter media, to remove arsenic and coliform bacteria from the water resource of small communities.

\section{Methods}

\subsection{Filter Media Preparation}

For filter media preparation, one of the essential stages is determination of solubility degree of filter media. This was determined in acidic media by dipping $10 \mathrm{~g}$ of each filter media in $32 \mathrm{~mL}$ of pure hydrochloric acid, which was mixed with $50 \%$ distilled water and was contacted for 30 minutes in the lab, with ambient temperature. The contacted filter media was rinsed, dried at $110^{\circ} \mathrm{C}$, and weighed. Finally, the degree of solubility was calculated by dividing the weight lost to the initial weight and multiplication by 100. It should be noted that the dissolution rate of each filter media was not $>5 \%$ (35).

\subsection{Experimental Setup}

The experimental setup of this study is illustrated in Figure 1. As indicated, the pilot plant consisted of several parts, such as 1 water reservoir and 3 separate filters. Each filter had a 9-cm inner diameter and $120 \mathrm{~cm}$ height and was prepared from Plexiglas tubes. Other parts consisted of an electro-pump and hose connections. The conventional SSF media was modified by zeolite and blast furnace slag (BFS). 
A

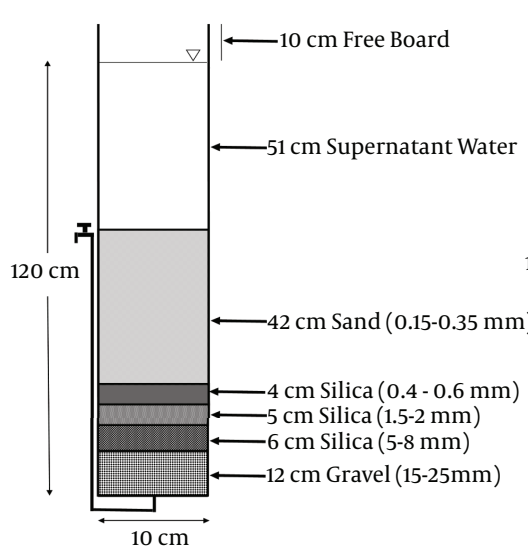

B

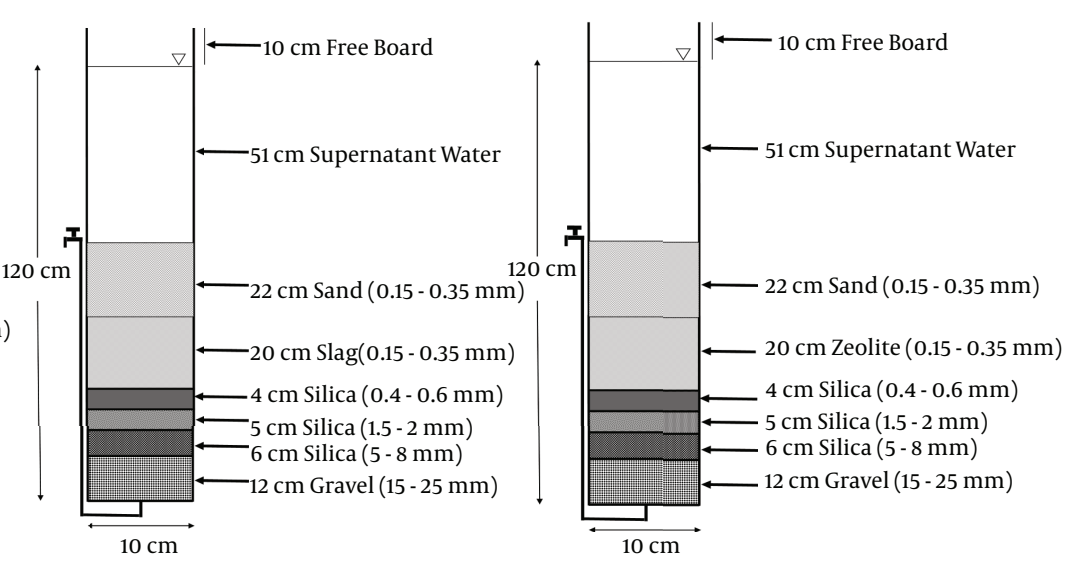

Figure 1. Pilot Plant Setup: A, Conventional SSF; B, Slag Modified Filter (SMF); C, Zeolite-modified filter (ZMF).

The pilot plant consisted of 3 separate filters with different media, which were prepared according to AWWA standards (36).

The first set of filter [Figure $1 \mathrm{~A}$ ] similar to conventional slow sand filters (SSFs) was filled only by sand as filter media. It was maintained as a control.

The second set of filter [Figure $1 \mathrm{~B}$ ] was modified by replacing the 20-cm blast furnace slag (BFS).

The third set of filter [Figure $1 \mathrm{C}$ ] was modified by replacing the $20-\mathrm{cm}$ natural zeolite, clinoptilolite.

In this study, water resource for all study stages was tap water that was supplied from deep wells around Zayandehroud river, Isfahan, center of Iran. Filtration rate was adjusted between 0.1 and $0.24 \mathrm{~m}^{3} / \mathrm{m}^{2} / \mathrm{h}$ (37). Thus, the flow rate of each filter was $1.5 \mathrm{~L} / \mathrm{h}$. Arsenic in the forms of $\mathrm{Na}_{2} \mathrm{HAsO}_{4} .7 \mathrm{H}_{2} \mathrm{O}$ and $\mathrm{NaAsO}_{2}$ was used for the preparation of stock synthetic solutions in distilled water $(6,38)$. Series of dilution were prepared from this stock in the range of $0.073,0.11,0.171,0.21,0.24$ and $0.33 \mathrm{mg} / \mathrm{L}$. Triplicate samples were taken after a 24-hour interval for each initial arsenic solution that was injected to the filters. The concentrations of arsenic were determined by ICP-AES (Model 2, Jobin Yvon ultima, France). The initial microbial stock solutions were prepared using diluted samples of Isfahan north wastewater treatment plant effluent and after samples were injected into the filters. Then, the total and fecal Coliforms were measured by multiple probable number (MPN) 9-tube method (39). Total hardness and turbidity of the samples were measured by titration with EDTA $0.01 \mathrm{M}$, and nephelometer (EUTECH TN-100), respectively (35). The cation exchange capacity (CEC) of filter media was measured by the methods used in previous studies $(35,40)$.

\section{Results}

Table 1 illustrates the characteristics of the filter media used in conventional sand filter and modified filters by zeolite and slag. The characteristics of the water samples used for the experiments are shown in Table 2. Table 3 shows arsenic concentrations of influent, finished water and its removal efficiencies by SSF, SMF, and ZMF. The trend of arsenic removal efficiencies and total coliform, fecal coliforms, turbidity and hardness removal (\%) by SSF, SMF, and ZMF are presented in Figure 2.

Table 1. Characteristics of the Filter Media Used in Conventional Sand Filter and Modified Filters by Zeolite and Slag

\begin{tabular}{lccc}
\hline Bed & Size, $\mathbf{m m}$ & Bed Weight, & Density, $\mathbf{~ k g} / \mathbf{m}^{\mathbf{3}}$ \\
\hline Sand & $0.15-0.35$ & 2.17 & 2173.9 \\
\hline Slag & $0.15-0.35$ & 2.85 & 2857.1 \\
\hline Zeolite & $0.15-0.35$ & 1.53 & 1538.4 \\
\hline Silica & $0.2-0.4$ & 2.63 & 2631.6 \\
\hline Silica & $0.5-0.8$ & 2.73 & 2739.7 \\
Silica & $1.5-2$ & 2.53 & 2531.6 \\
\hline Gravel & $15-25$ & 2.56 & 2564.1 \\
\hline
\end{tabular}

The mean removal efficiency of hardness, turbidity, and total coliforms by SSF, SMF, and ZMF are tabulated in Figures 3.

\section{Discussion}

Table 3 and Figure 2 show the trend of arsenic removal is the same in the three filter media. Therefore, in all in- 
Table 2. Characterization of the Water Samples Used for the Experiments

\begin{tabular}{lc}
\hline Parameter & Mean \pm SD \\
\hline pH & $7.2 \pm 0.13$ \\
\hline Temperature, ${ }^{\circ} \mathbf{C}$ & $23 \pm 0.5$ \\
\hline Turbidity, NTU & $1 \pm 0.5$ \\
\hline TDS, $\mathbf{~ m g / L}$ & $645.9 \pm 277.8$ \\
\hline EC & $1030 \pm 340.5$ \\
\hline Total Hardness, $\mathbf{~ m g / L ~ a s ~ C a c O ~}$ & \\
\hline Alkalinity, $\mathbf{~ m g / L ~ a s ~ C a c O 3 ~}$ & $750 \pm 406.6$ \\
\hline Total coliform, $\mathbf{M P N} / \mathbf{1 0 0} \mathbf{~ m L}$ & $163.1 \pm 28.8$ \\
\hline Fecal coliform, $\mathbf{M P N} / \mathbf{1 0 0} \mathbf{~ m L}$ & $4 \times 10^{6} \pm 1428$ \\
\hline Arsenic, $\mathbf{~ m g / L}$ & $171.8 \pm 115.5$ \\
\hline
\end{tabular}

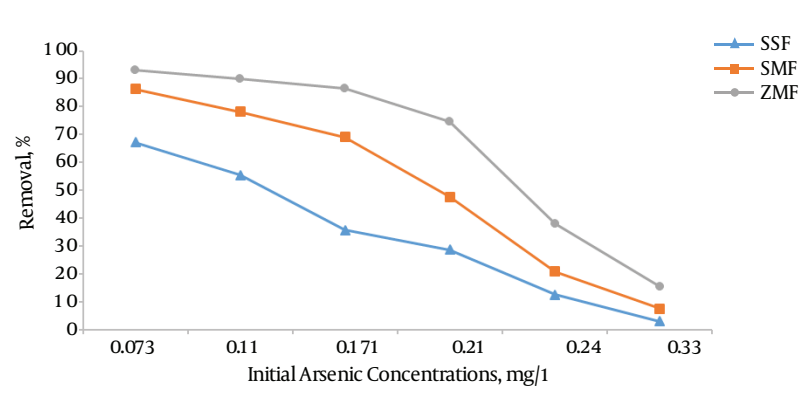

Figure 2. The Trend of Arsenic Removal Efficiencies by SSF, SMF, and ZMF

fluent water, the highest and the lowest removal efficiencies were obtained at low and high arsenic concentrations ( 0.073 and $0.33 \mathrm{mg} / \mathrm{L}$ ), respectively. In other words, by increasing the influent arsenic concentrations, the arsenic removal efficiencies were decreased, so that, in the 0.33 $\mathrm{mg} / \mathrm{L}$ arsenic concentration, the filters practically did not show high efficiency in arsenic removal. This may be due to the high initial concentration of arsenic, low area of filters, and saturation of media adsorption sites during operation of the filters Rany Devi et al. 2008, showed that by increasing treatment time, the adsorbent sites of the media would tend towards saturation (4). The highest removal efficiencies of arsenic that were obtained in a concentration of $0.073 \mathrm{mg} / \mathrm{l}$ by SSF, SMF, and ZMF, were $67.1 \%, 86.3 \%$, and 93.1\%, respectively. Overall, the mean removal efficiencies of SSF, SMF, and ZMF were $33.7 \%, 51.5 \%$, and $66.2 \%$, respectively. The priority removal efficiency of the 3 studied media is as follows: $\mathrm{R}_{\mathrm{ZMF}}>\mathrm{R}_{\mathrm{SMF}}>\mathrm{R}_{\mathrm{SSF}}$.

In comparison, the studied filters indicated that SSF in any of the initial concentrations of arsenic couldn't meet the WHO guidelines. However, the SMF only in the initial concentration of $0.073 \mathrm{mg} / \mathrm{L}$ and the ZMF in concentra- tions of 0.073 and $0.11 \mathrm{mg} / \mathrm{L}$ could meet WHO guidelines. The corresponding removal efficiencies by ZMF were $93.1 \%$ and $90 \%$, respectively. Nitzsche et al. in 2013 reported $96 \%$ arsenic removal for the initial concentration of $0.115 \mathrm{mg} / \mathrm{L}$ by using household filters (33). Most of these technologies could be used for As removal in large and medium scale treatment plants for centralized services, yet are not appropriate for rural areas where only untrained operators are available to install and maintain these technologies for domestic use. Other technologies accomplish similarly or even better outcomes regarding their As removal efficiencies, e.g., chemical coagulation or electrocoagulation (depending on As species up to $93 \%$ to $99 \%$ As removal efficiency (41) or pressure-driven membrane-based methods such as nano-filtration or reverse osmosis; both up to $99 \%$ arsenate removal efficiency. However, these techniques are much more expensive than the simple sand filter systems and have a high operation and maintenance cost. Some methods, such as oxidation treatments by ozone or coagulation-flocculation, require the addition of chemical compounds that produce toxic or carcinogenic by-products. Filters based on activated carbon are not as efficient regarding adsorption, having an AS removal efficiency of only up to $60 \%$ (42).

Although, all three filter media, SSF, ZMF, and SMF, had partial arsenic removal efficiencies and their mechanisms could be cation exchange capacity, adsorption, and precipitation, but among them, the ZMF showed the highest arsenic removal efficiency, due to having a high cation exchange capacity, sorption and precipitation more than slag and sand. The SMF also showed a satisfactory removal efficiency compared to the SSF, which may be due to adsorption, precipitation or complexation of AS on iron oxide present in BFS (43). The CEC of filter media is another important factor to enhance the removal efficiency of arsenic. The CEC of SSF, SMF and ZMF were 4.8, 6.3 and 6.55 (meq/g), respectively. These results confirm that CEC in the zeolite is more than slag and sand. Therefore, it is clear that efficiency of zeolite media is more than other media due to high CEC.

$$
\mathrm{CEC}_{\mathrm{ZMF}}>\mathrm{CEC}_{\mathrm{SMF}}>\mathrm{CEC}_{\mathrm{SSF}}
$$

Thus, the modified filters with low-cost adsorbents, Zeolite, and Blast furnace slag, had better efficiency for arsenic removal than the conventional sand filters Rany Devi et al. 2008, Shafiquzzaman et al. 2011 and Aviles et al. 2013 obtained the same results $(4,13,24)$. In addition, similar results were achieved by Yu et al. 2013, Chutia et al. 2009 and Sublet et al. 2003. which used low-cost adsorbents for lead and arsenic removal $(22,44,45)$.

Figure 3 shows mean removal efficiency of hardness, turbidity, and total coliforms by SSF, SMF, and ZMF. As can be seen, total hardness removal with average inlet concen- 
Table 3. Arsenic Concentrations of Influent, Finished Water and its Removal Efficiencies by SSF, SMF and ZMF

\begin{tabular}{|c|c|c|c|c|c|c|}
\hline \multirow[t]{2}{*}{ Initial Arsenic Concentration ${ }^{a}$} & \multicolumn{2}{|c|}{ SSF } & \multicolumn{2}{|c|}{ SMF } & \multicolumn{2}{|c|}{ ZMF } \\
\hline & Outlet $^{\mathbf{a}}$ & \% Removal & Outlet $^{\mathbf{a}}$ & \% Removal & Outlet $^{\mathbf{a}}$ & \% Removal \\
\hline 0.073 & 0.024 & 67.1 & 0.01 & 86.3 & 0.005 & 93.1 \\
\hline 0.11 & 0.049 & 55.4 & 0.024 & 78.1 & 0.011 & 90 \\
\hline 0.171 & 0.11 & 35.6 & 0.053 & 69 & 0.023 & 86.5 \\
\hline 0.24 & 0.21 & 12.5 & 0.19 & 20.8 & 0.149 & 37.9 \\
\hline 0.33 & 0.33 & 3 & 0.305 & 7.5 & 0.28 & 15.1 \\
\hline
\end{tabular}

${ }^{\mathrm{a}}$ As mg/L.

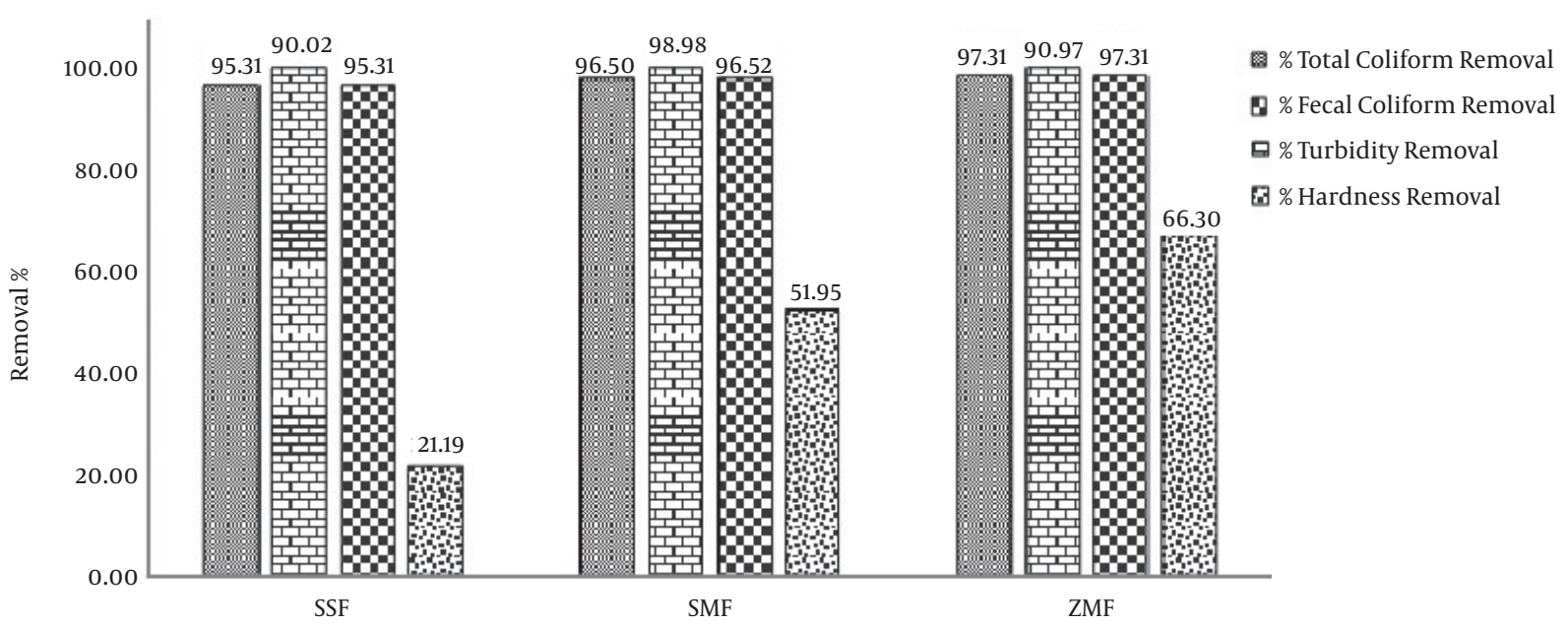

Figure 3. Total Coliform, Fecal Coliforms, Turbidity and Hardness Removal (\%), by SSF, SMF, and ZMF

tration of $759 \mathrm{mg} / \mathrm{L}$, was $21.1 \%, 51.9 \%$, and $66.3 \%$ by SSF, SMF, and ZMF, respectively. This shows that ZMF can remove the higher amounts of arsenic and other pollutants compared to other studied filters (35). However, for water turbidity removal, with average influent turbidity of 30 NTU, approximately the same efficiencies of $98.8 \%, 98.9 \%$, and 98.9\% were achieved by SSF, SMF, and ZMF, respectively.

The world health organization (WHO) suggested 2 logs as the lowest reductions of bacteria, achieved by water treatment technologies, such as slow sand filters (16). In the present study, the total coliform of influent water was $4 * 10^{6}$ (MPN/100 mL). The calculated bacteria reductions of the 3 investigated filter media, SSF, SMF, and ZMF were 1.97, 1.98 and $1.99 \log$, respectively. The conventional sand filter and modified filters by zeolite and slag had almost the same removal efficiency of coliform bacteria. Because the main reason for the removal of coliform bacteria in filters bed biological film (Schmutzdeck) formed on the surface of the filter. The biological film was present on each of the three filters.

Similar results were achieved by Baig et al. 2011 and Mahmood et al. 2011 for total coliforms removal $(10,46)$.

It was noted that the difference in the removal percentage of arsenic, total hardness, total and fecal coliform, and turbidity could be related to the difference in tendency of these pollutants for adsorption towards the studied filter media (4).

\subsection{Conclusions}

It is concluded from this study that slag and zeolite modified filters, especially zeolite, could be used for water treatment in many rural areas or small communities of developing countries that have hardness, arsenic, turbidity, and coliform problems in their water resources. Other reasons may be that these materials are low cost, and also their 
assembling is easy. For the promotion of these filter efficiencies in future studies, it is recommended to enhance media depth and surface.

\section{Acknowledgments}

This study was an MSc approved research project (No. 391079) performed at Isfahan University of Medical Sciences, Iran. The authors are thankful for the funding provided by the department of environmental health engineering and environment research center.

\section{References}

1. Ebrahimi A, Mahdavi M, Ghasemian A, Poursafa P, Sharifi F, Mohammadi $\mathrm{R}$, et al. Trends in health burden of untreated water and insanitary environments in Iran, 1990-2010: Findings from the global burden of disease study 2010. Med J Islamic Republic Iran. 2016;30:424

2. Xia S, Nan J, Liu R, Li G. Study of drinking water treatment by ultrafiltration of surface water and its application to China. Desalination. 2004;170(1):41-7. doi: 10.1016/j.desal.2004.03.014.

3. Jenkins MW, Tiwari SK, Darby J. Bacterial, viral and turbidity removal by intermittent slow sand filtration for household use in developing countries: experimental investigation and modeling. Water Res. 2011;45(18):6227-39. doi: 10.1016/j.watres.2011.09.022. [PubMed: 21974872].

4. Devi R, Alemayehu E, Singh V, Kumar A, Mengistie E. Removal of fluoride, arsenic and coliform bacteria by modified homemade filter media from drinking water. Bioresour Technol. 2008;99(7):2269-74. doi: 10.1016/j.biortech.2007.05.002. [PubMed: 17596936].

5. Lukasik J, Cheng YF, Lu F, Tamplin M, Farrah SR. Removal of microorganisms from water by columns containing sand coated with ferric and aluminum hydroxides. Water Res. 1999;33(3):769-77. doi: 10.1016/s0043-1354(98)00279-6.

6. Nemade PD, Kadam AM, Shankar HS. Removal of iron, arsenic and coliform bacteria from water by novel constructed soil filter system. Ecol Engin. 2009;35(8):1152-7. doi:10.1016/j.ecoleng.2009.03.013.

7. Jain CK, Singh RD. Technological options for the removal of arsenic with special reference to South East Asia. JEnviron Manage. 2012;107:118. doi: 10.1016/j.jenvman.2012.04.016. [PubMed: 22579769].

8. Baig SA, Sheng T, Hu Y, Lv X, Xu X. Adsorptive removal of arsenic in saturated sand filter containing amended adsorbents. Ecol Engin. 2013;60:345-53. doi:10.1016/j.ecoleng.2013.09.001.

9. Dastgiri S, Mosaferi M, Fizi MA, Olfati N, Zolali S, Pouladi N, et al. Arsenic exposure, dermatological lesions, hypertension, and chromosomal abnormalities among people in a rural community of northwest Iran. J Health Popul Nutr. 2010;28(1):14-22. [PubMed: 20214082].

10. Mahmood Q, Baig SA, Nawab B, Shafqat MN, Pervez A, Zeb BS. Development of low cost household drinking water treatment system for the earthquake affected communities in Northern Pakistan. Desalination. 2011;273(2-3):316-20. doi:10.1016/j.desal.2011.01.052.

11. Onnby L, Pakade V, Mattiasson B, Kirsebom H. Polymer composite adsorbents using particles of molecularly imprinted polymers or aluminium oxide nanoparticles for treatment of arsenic contaminated waters. Water Res. 2012;46(13):4111-20. doi: 10.1016/j.watres.2012.05.028. [PubMed: 22687522].

12. Wang Y, Tsang DC. Effects of solution chemistry on $\operatorname{arsenic}(V)$ removal by low-cost adsorbents. J Environ Sci (China). 2013;25(11):2291-8. [PubMed: 24552058].
13. Shafiquzzaman M, Azam MS, Nakajima J, Bari QH. Investigation of arsenic removal performance by a simple iron removal ceramic filter in rural households of Bangladesh. Desalination. 2011;265(1):60-6.

14. Matschullat J. Arsenic in the geosphere-a review. Sci Total Environ. 2000;249(1-3):297-312. [PubMed:10813460].

15. Gupta A, Chaudhuri M. Enteric virus removal/inactivation by coalbased media. Water Res. 1995;29(2):511-6.

16. WHO . Guidelines for drinking-water quality. ; 2011.

17. Pio I, Scarlino A, Bloise E, Mele G, Santoro O, Pastore T, et al. Efficient removal of low-arsenic concentrations from drinking water by combined coagulation and adsorption processes. Separat Purif Technol. 2015;147:284-91. doi: 10.1016/j.seppur.2015.05.002.

18. Song S, Gallegos-Garcia M. In: The Role of Colloidal Systems in Environmental Protection. Fanun M, editor. Amsterdam: Elsevier; 2014 pp. 261-77.Chapter 11-Arsenic Removal from Water by the Coagulation Process.

19. Terracciano A, Ge J, Meng X. A comprehensive study of treatment of arsenic in water combining oxidation, coagulation, and filtration.JEnviron Sci (China). 2015;36:178-80. doi:10.1016/j.jes.2015.08.001. [PubMed: 26456620]

20. Wu K, Liu RP, Liu HJ, Lan HC, Qu JH. Enhanced arsenic removal by in situ formed Fe-Mn binary oxide in the aeration-direct filtration process. I Hazard Mater. 2012;239-240:308-15. doi: 10.1016/j.jhazmat.2012.08.079. [PubMed: 23017236].

21. Pal P, Chakrabortty S, Linnanen L. A nanofiltration-coagulation integrated system for separation and stabilization of arsenic from groundwater. Sci Total Environ. 2014;476-477:601-10. doi: 10.1016/j.scitotenv.2014.01.041. [PubMed: 24496033].

22. Yu Y, Zhao C, Wang Y, Fan W, Luan Z. Effects of ion concentration and natural organic matter on arsenic(V) removal by nanofiltration under different transmembrane pressures. J Environ Sci (China). 2013;25(2):302-7. [PubMed: 23596950].

23. Abejon A, Garea A, Irabien A. Arsenic removal from drinking water by reverse osmosis: Minimization of costs and energy consumption. Separat PurifTechnol. 2015;144:46-53. doi:10.1016/j.seppur.2015.02.017.

24. Aviles M, Garrido SE, Esteller MV, De la Paz JS, Najera C, Corte J. Removal of groundwater arsenic using a household filter with iron spikes and stainless steel. J Environ Manage. 2013;131:103-9. doi: 10.1016/j.jenvman.2013.09.037. [PubMed: 24157410].

25. Rahman IM, Begum ZA, Sawai H, Maki T, Hasegawa H. Decontamination of spent iron-oxide coated sand from filters used in arsenic removal. Chemosphere. 2013;92(2):196-200. doi: 10.1016/j.chemosphere.2013.03.024. [PubMed: 23591134].

26. Rozell D. Modeling the Removal of Arsenic by Iron Oxide Coated Sand. J Environ Engin. 2010;136(2):246-8. doi: 10.1061/(asce)ee.1943 7870.0000138.

27. Hsu JC, Lin CJ, Liao CH, Chen ST. Removal of As(V) and As(III) by reclaimed iron-oxide coated sands. J Hazard Mater. 2008;153(1-2):817-26. doi:10.1016/j.jhazmat.2007.09.031. [PubMed: 17988793].

28. Guan X, Du J, Meng X, Sun Y, Sun B, Hu Q. Application of titanium dioxide in arsenic removal from water: A review. J Hazard Mater. 2012;215216:1-16. doi: 10.1016/j.jhazmat.2012.02.069. [PubMed: 22445257].

29. Xu T, Cai Y, O'Shea KE. Adsorption and photocatalyzed oxidation of methylated arsenic species in $\mathrm{TiO} 2$ suspensions. Environ Sci Technol. 2007;41(15):5471-7. [PubMed: 17822119].

30. Qiu W, Zheng Y. Arsenate removal from water by an aluminamodified zeolite recovered from fly ash. I Hazard Mater 2007;148(3):721-6. doi: 10.1016/j.jhazmat.2007.03.038. [PubMed $17452074]$.

31. Shafique U, Ijaz A, Salman M, Zaman W, Jamil N, Rehman R, et al. Removal of arsenic from water using pine leaves. J Taiwan Inst Chem Engin. 2012;43(2):256-63. doi: 10.1016/j.jtice.2011.10.006.

32. Bilici Baskan M, Pala A. Removal of arsenic from drinking water using modified natural zeolite. Desalination. 2011;281:396-403. doi: 10.1016/j.desal.2011.08.015. 
33. Nitzsche KS, Lan VM, Trang PT, Viet PH, Berg M, Voegelin A, et al. Arsenic removal from drinking water by a household sand filter in Vietnameffect of filter usage practices on arsenic removal efficiency and microbiological water quality. Sci Total Environ. 2015;502:526-36. doi: 10.1016/j.scitotenv.2014.09.055. [PubMed: 25300017].

34. Dimitrova SV. Use of granular slag columns for lead removal. Water Res. 2002;36(16):4001-8. doi:10.1016/s0043-1354(02)00120-3.

35. Ebrahimi A, Jafari N, Abdolahnejad A. Application of Iranian natural zeolite and blast furnace slag as slow sand filters media for water softening. Int J Environ Health Engin. 2014;3(1):26. doi: 10.4103/22779183.139742.

36. AWWA. Standard for Granular Filter Material. Colorado, Denver, USA: American Water Works Association, ANSI/AWWA B100-01. ; 2002.

37. AWWA. Water Treatment Plant Design. USA: McGraw-Hill; 2005.

38. Bina B, Ebrahimi A, Hesami F, Amin MM. Arsenic removal by coagulation using ferric chloride and chitosan from water. Int J Environ Health Engin. 2013;2(1):17. doi: 10.4103/2277-9183.110170.

39. Association APH . Standard methods for the examination of water and wastewater. ; .

40. Sivasankar V, Ramachandramoorthy T. Water softening behaviour of sand materials-Mimicking natural zeolites in some locations of Rameswaram Island, India. Chem Engin J. 2011;171(1):24-32. doi: 10.1016/j.cej.2011.03.032.
41. Ratna Kumar P, Chaudhari S, Khilar KC, Mahajan SP. Removal of arsenic from water by electrocoagulation. Chemosphere. 2004;55(9):1245-52. doi: 10.1016/j.chemosphere.2003.12.025. [PubMed: 15081765].

42. Mondal P, Bhowmick S, Chatterjee D, Figoli A, Van der Bruggen B. Remediation of inorganic arsenic in groundwater for safe water supply: a critical assessment of technological solutions. Chemosphere. 2013;92(2):157-70. doi: 10.1016/j.chemosphere.2013.01.097. [PubMed: 23466274].

43. Kanel SR, Choi H, Kim JY, Vigneswaran S, Shim WG. Removal of Arsenic (III) from Groundwater using Low-Cost Industrial By-products- Blast Furnace Slag. Water Qual Res J Can. 2006;41(2):130-9.

44. Chutia P, Kato S, Kojima T, Satokawa S. Arsenic adsorption from aqueous solution on synthetic zeolites. J Hazard Mater. 2009;162(1):440-7. doi: 10.1016/j.jhazmat.2008.05.061. [PubMed: 18583035].

45. Sublet R, Simonnot MO, Boireau A, Sardin M. Selection of an adsorbent for lead removal from drinking water by a pointof-use treatment device. Water Res. 2003;37(20):4904-12. doi: 10.1016/j.watres.2003.08.010. [PubMed:14604636].

46. Baig SA, Mahmood Q, Nawab B, Shafqat MN, Pervez A. Improvement of drinking water quality by using plant biomass through household biosand filter - A decentralized approach. Ecol Engin. 2011;37(11):18428. doi:10.1016/j.ecoleng.2011.06.011. 